\title{
Cruce et Aratro: Fascism, Missionary Schools, and Labor in 1920s Italian Somalia
}

\section{Caterina Scalvedi}

\section{INTRODUCTION}

In May 1928, the Catholic missionary journal La Consolata opened with a piece titled "Cruce et Aratro." The anonymous author wrote that in Somalia "we [Italian missionaries] colonize only through the plow [aratro] and the cross [cruce], and by 'colonize' here we mean civilize." Earlier missionary work had proved such a strategy to be successful in the neighboring British colony of Kenya. For twenty-five years, the fathers had "civilized" men and women through nuns' "heroic charity" and increased "material wealth resulted from physical work." What the Italian missionaries had achieved for the British-the transformation of African subjects into Christians and workers- had to be achieved in Somalia. ${ }^{1}$

Scholarship on Italian colonialism in Somalia has addressed the study of developmentalist discourses and practices from both the colonial

1 "Cruce et Aratro," May 1928, La Consolata ( $L C)$. All primary sources quoted in this paper are in Italian in the original; all translations from Italian into English are mine.

C. Scalvedi $(\square)$

University of Illinois at Chicago, Chicago, IL, USA

e-mail: cscalv2@uic.edu

(C) The Author(s) 2020

D. Matasci et al. (eds.), Education and Development in Colonial and Postcolonial Africa, Global Histories of Education, https://doi.org/10.1007/978-3-030-27801-4_6 
period (1908-1941) and the postwar UN trust mandate of Italian administration (1949-1960). ${ }^{2}$ Historians have retraced how, with the arrival of the first fascist governor in the colony in 1923, the colonial state planned ambitious policies of agricultural and infrastructural expansion. Its goal was to prepare for the military conquest of neighboring Ethiopia, later achieved during the Second Italo-Ethiopian War in 1935-1936. It was thus no coincidence that in 1928 La Consolata depicted Somalia as "Italy's most promising colony." 3 Public and private investments aimed at the creation of a plantation system for crop export to Italy in the fertile southern regions of Somalia. Further, both private companies and the colonial state tried to resolve the shortage of workforce through coercive practices including native land expropriation, the promotion of forced marriages for the reproduction of labor, and the legalization of forced labor. ${ }^{4}$ According to Annalisa Urbano, the development (valorizzazione) of Somalia was an evolving discourse that provided both a justification and a scope for the colonial venture. Colonial authorities legitimized forced labor recruitment as part of a modernizing strategy and "school of progress" for locals. Ultimately, she has shown, the investment in plantation agriculture and related decrease in the production

\footnotetext{
${ }^{2}$ Robert L. Hess, Italian Colonialism in Somalia (Chicago: University of Chicago Press, 1966); Michele Pandolfo, "La Somalia coloniale: una storia ai margini della memoria italiana," Diacronie 14, no. 2 (2013): 1-18; Gianluca Podestà, Il mito dell'impero. Economia, politica e lavoro nelle colonie italiane dell'Africa orientale 1898-1941 (Turin: G. Giappicchelli Editore, 2004), 199-225; Andrea Naletto, Italiani in Somalia. Storia di un colonialismo straccione (Padua: Cierre edizioni, 2011); Riccardo Tesolin, Investive in colonia. Somalia italiana e Côte Française des Somalis 1920-1960 (M.A. diss., University of Bologna, 2018); Ercole Tuccimei, La Banca d'Italia in Africa (Bari: Laterza, 1999). On developmentalist planning in 1949-1960, see Antonio Maria Morone, "Politica e istruzione nella Somalia sotto tutela italiana," in Colonia e Postcolonia come spazi diasporici, ed. by Uoldelul Chelati Dirar et al. (Rome: Carocci, 2011), 75-92.

3 "Cruce et Aratro," May 1928, LC.

${ }^{4}$ On labor in Italian Somalia, see Lee V. Cassanelli, "The End of Slavery and the 'Problem' of Farm Labor in Colonial Somalia," and Hassan O. Ahmed, "Sul primo decennio dell'era fascista in Somalia," both in Proceedings of the Third International Congress of Somali Studies: History, Anthropology and Archaeology, ed. by Annarita Puglielli and Francesco Antinucci (Rome: Pensiero Scientifico Editore, 1988), 269-282 and 291-297; Francesca Declich, "Italian Weddings and Memory of Trauma: Colonial Domestic Policy in Southern Somalia, 1910-1941," in Marriage by Force? Contestation Over Consent and Coercion in Africa, ed. by Annie Bunting et al. (Athens: Ohio University Press, 2016), 70-83; Angelo Del Boca, Italiani, Brava Gente? Un mito duro a morire (Vicenza: Neri Pozza, 2005).
} 
for the local market made Somalia dependent on imports, which had a long-standing impact on postwar international programs for the development of the region. ${ }^{5}$

Colonial state, private businesses, credit institutes, and the exploited workforce are the protagonists of this historiography on "civilization through labor" in Italian Somalia. This essay's goal is to introduce two key actors that remain missing from the picture: the Catholic Church and education. I show that, as a result of fascist and Vatican converging agendas, missionaries occupied a leading role in the shaping of developmental discourses and practices in Italian Somalia. They did so by creating the colony's first school system and by making of labor the core of education. While highlighting the peculiarities of the cruce et aratro project as undertaken in Italian Somalia, I argue that it reflected broader trends both in religious and racial policy in Italian colonialism as well as in interwar educational and labor policies throughout Africa. ${ }^{6}$

In conducting this study, I relied on the archives of the Consolata Missions Institute (CMI) in Rome, Italy. ${ }^{7}$ The Consolata Fathers directed all the Italian educational initiatives in the colony from 1924 to $1930,{ }^{8}$ leaving a rich set of primary sources including the correspondence with

${ }^{5}$ Annalisa Urbano, "A 'Grandiose Future for Italian Somalia': Colonial Developmentalist
Discourse, Agricultural Planning, and Forced Labor (1900-1940)," International Labor and Working-Class History 92 (2017): 69-88.

${ }^{6}$ On the relationship between education and labor in colonial Africa, see two recent volumes: Developing Africa: Concepts and Practices in Twentieth-Century Colonialism, ed. by Joseph M. Hodge et al. (Manchester: Manchester University Press, 2014); Empire and Education in Africa: The Shaping of a Comparative Perspective, ed. by Peter Kallaway and Rebecca Swartz (New York: Peter Lang, 2016).

${ }^{7}$ Founded by Giuseppe Allamano in Turin (1901), the CMI was created to promote evangelization and education in Africa. In its first twenty-five years, the CMI sent missionaries also to the Kaffa region in southwestern Ethiopia, East British Africa (Kenya and Tanzania), and Mozambique. On the history of the Institute and its archives, see Alberto Sbacchi, "The Archives of the Consolata Mission and Italian Colonialism," in vol. I of Fonti e problemi della politica coloniale italiana: atti del convegno Taormina-Messina, 23-29 ottobre 1989, ed. by Carla Ghezzi (Rome: Ministero per i beni culturali e ambientali, Ufficio Centrale per i beni archivistici, 1997), 87-112.

${ }^{8}$ Two studies have provided surveys of Consolata missionary work in Italia Somalia: Bianca Maria Carcangiu, "I Missionari della Consolata nella Somalia italiana (19251930)," in Studi mediterranei ed extraeuropei, ed. by Vittorio Antonio Salvadorini (Pisa: Edistudio, 2002), 147-174; Daniele Natilli, "Le missioni cattoliche italiane all'estero: il caso della Consolata nella Somalia di Cesare Maria De Vecchi (1924-1928)," A.S.E.I. 
fascist authorities, private letters, and self-reports. I have also consulted the official documentation produced by and stored at Italian and Vatican governmental institutions. ${ }^{9}$ These sources provide insights into the quotidian life and administration of the colony. ${ }^{10}$

\section{Church-State Reconciliation}

In her book on Trinitarian missions in Italian Somalia (1903-1924), the historian Lucia Ceci shows how, up to the early 1920s, the Catholic presence in Somalia was very weak due to colonial authorities' anticlericalism and the missionaries' lack of both human and financial resources. ${ }^{11}$ In 1904, the Congregation for the Propagation of the Faith founded the Vicariate of Benadir, comprising the Benadir coastal area under Italian protectorate to become the colony of Italian Somalia in 1908. The Congregation promoted abolitionism and assistance for freed slaves in a region where slavery was still widely practiced. Rulers supported the anti-slavery project but prevented missionaries from any activity of religious proselytism that could create tensions with the local Muslim society. The Trinitarians' duty was to provide for charity and to train locals

(7 November 2011), accessed February 28, 2019, https://www.asei.eu/it/2011/11/ le-missioni-cattoliche-italiane-allestero-il-caso-della-consolata-nella-somalia-di-cesare-maria-de-vecchi-1924-1928/.

${ }^{9}$ All archives are in Rome, Italy: Archivio Centrale dello Stato. Ministero dell'Africa Italiana (ACS-MAI); Archivio dell'Istituto Missioni Consolata (AIMC); Archivio Storico Generale dei Frati Minori (AOFM); Archivio Storico Diplomatico del Ministero degli Affari Esteri. Ministero dell'Africa Italiana (ASDMAE-MAI) and Archivi di personalità. Guido Corni 1928-1931 (ASDMAE-Corni); Archivio Storico di Propaganda Fide (ASPF).

${ }^{10}$ Missionaries wrote about their routine and difficulties, published articles in the magazine of the Institute, La Consolata, and took pictures of everyday life, people, and landscapes. Photographs are located at the Archivio Fotografico Istituto Missioni Consolata (AFIMC) in Turin, Italy, and at the Fondi iconografici della Biblioteca di Storia Moderna e Contemporanea e del Museo centrale del Risorgimento di Roma (BSMC) in Rome, Italy.

${ }^{11}$ Lucia Ceci, Il vessillo e la croce. Colonialismo, missioni cattoliche e islam in Somalia (1903-1924) (Bologna: Il Mulino, 2006). According to the agreement between Trinitarians and the colonial rulers (July 1923), "missionaries commit themselves to abstain from any propaganda or interference [with religious beliefs and practices] as they respect the religious sentiment of students and pursue an exclusively civil mission towards the moral elevation and improvement [of students]" (Art. 2). See Carlo Riveri, "Convenzione con Trinitari sulle scuole," 9 July 1923, AIMC VIII 6,1. 
as Italian language speaking skilled workers that one day could serve the labor needs of the Italian settler community. While Italian settlers paid for their children's school equipment, the colonial government entirely funded the local youth's education. ${ }^{12}$ By 1923, Trinitarians had built three missionary stations in Mogadishu, Gelib, and Brava. ${ }^{13}$

Liberal authorities, in other words, encouraged the plow (aratro) but strictly prohibited the cross (cruce). Things would change with the arrival of the fascist governor Cesare Maria De Vecchi (1923-1928) and Consolata missionaries, Trinitarians' successors (1924-1930). On the one hand, De Vecchi pursued a resolute policy of direct rule through territorial expansion, native land expropriation, and increased Italian settlement. The consequent centralization of Italian rule and internal pacification of the colony paved the way for missionary activities. Not only missionaries could work under the colonial state's stronger protection, but the colonial state itself increasingly needed missionary work in the form of both the plow and the cross. De Vecchi launched infrastructure building projects as well as extended and intensified agricultural exploitation of newly acquired lands: the need for labor was high. Simultaneously, the Catholic settler population almost doubled in a few years (from 674 in 1921 to 1200 in 1929), ${ }^{14}$ and the governor created a native army (Corpo Zaptie) whose members were to be granted with basic public services including Italian language teaching and healthcare. A fervent Catholic, De Vecchi announced that he aimed to intensify religious proselytizing, deploring previous governors' prohibitions. ${ }^{15}$ Trinitarians, lacking funds and internally divided, abandoned Somalia a few weeks later. ${ }^{16}$

${ }^{12}$ Gabriele Perlo to Filippo Perlo, 13 November 1924, AIMC VIII 6,1.

${ }^{13}$ Prima relazione integrale inviata alla S.C. di Propaganda Fide sullo stato della Prefettura Apost. Della Somalia Italiana, AIMC VIII 6,1. See also La partenza dei Missionari della Consolata per la Somalia Italiana, 12 October 1924, insert of LC.

${ }^{14}$ Nicola Labanca, "Italiani d'Africa," in Adua. Le ragioni di una sconfitta, ed. by Angelo Del Boca (Bari: Laterza, 1998), 210. On the 1920s as decade of transition, see also Gian Paolo Calchi Novati, L'Africa d'Italia. Una storia coloniale e postcoloniale (Rome: Carocci, 2011), 188.

${ }^{15}$ De Vecchi removed the ban on proselytism soon after he landed in the colony. See Report by Alessandro Parenti to the Congregation for the Propagation of the Faith, 25 January 1924, AIMC VIII 6,1.

${ }^{16}$ Only a Trinitarian missionary, Alessandro Parenti, stayed in the colony and worked with Consolata missionaries. See the correspondence between Alessandro Parenti, Francesco Gamberutti, Gabriele and Filippo Perlo, 1924-1925, AIMC VIII 6,1. 
In 1924, on the other hand, Consolata missionaries replaced Trinitarians as a result of an agreement between De Vecchi and the Congregation for the Propagation of Faith. ${ }^{17}$ Evidence suggests that the Italian Ministry of the Colonies was closely following CMI's work in Africa and thinking about their possible replacement of Trinitarians since 1917. Italian authorities valued several factors. First, during the First World War missionaries had shown their devotion to Italy by sending letters of support for the military victories of the Italian army in the peninsula. Second, in British East Africa (Kenya), the mission had started medical activities and professional courses for the African youth. Through religious and commercial activities, Consolata missionaries had also penetrated in southwestern Ethiopia, a region the Italian government was interested in for a potential plan of expansion. ${ }^{18}$ For these reasons, colonial authorities viewed the Consolata Fathers as champions of Italian loyalty and colonial agents professionally specialized in the vocational education of African subjects. ${ }^{19}$

Missionary work in Italian Somalia, however, was not only in the agenda of the Italian state. On the Vatican side, the work of Consolata missionaries was part of an ongoing missionary strategy plan set by Benedict XV and his successor Pius XI. In 1919 and 1926, the two Popes respectively published the apostolic letter Maximum Illud and the encyclical Rerum Ecclesiae exhorting evangelization among "pagan" people as a supranatural endeavor separated from national and imperial aims. The ultimate goal of missionaries, according to both documents, was the expansion of the kingdom of God, not an empire of man. ${ }^{20}$

\footnotetext{
${ }^{17}$ See "Azione della missione Cattolica nella Somalia Italiana - Trinitari scalzi," "Somalia Chiese e Missioni," "Missioni religiose in Somalia "Consolata'," and "Somalia Vicariato Apostolico," in ASDMAE-MAI I 89/15; "Somalia Passaporti e Lasciapassare Passaporti per Missionari," in ASDMAE-MAI I 89/18.

${ }^{18}$ See correspondence in "Missioni cattoliche e culti 1914-1918," ASDMAE-MAI III 156.

${ }^{19} \mathrm{Ceci}$, Il vessillo e la croce, 222-223.

${ }^{20}$ The publication of both documents was strongly influenced by the ideas of Cardinal Willem Marinus van Rossum, prefect of the Congregation for the Propagation of the Faith (1918-1932). See Benedict XV, Maximum Illud, apostolic letter, November 30, 1919, Vatican Web site, accessed February 28, 2019, http://w2.vatican.va/content/benedict-xv/en/apost_letters/documents/hf_ben-xv_apl_19191130_maximum-illud.html; Pius XI, Rerum Ecclesiae, encyclical letter, February 28, 1926, Vatican website, accessed February 28, 2019, http://w2.vatican.va/content/pius-xi/en/encyclicals/documents/ hf_p-xi_enc_28021926_rerum-ecclesiae.html. As part of the Holy See's evangelization
} 
In fact, CMI adopted an explicitly pro-Italian attitude that seemed to contrast the encyclical's scope: La Consolata consistently praised Italy's colonial presence in Somalia as well as emphasized the "Italian" character of missionary teaching. ${ }^{21}$ I found no evidence suggesting that CMI's posture played a role in either the choice or later replacement of Consolata missionaries by Vatican authorities-whereas it certainly influenced Italian authorities' active support of their work. Most likely, the Pope prioritized the good and cooperative relationship between the Catholic Church and the (highly nationalist) fascist state as a precondition to evangelization in Italian colonies, especially given that such a relationship came after a long season of Italian authorities' strong anticlericalism and diffidence toward Catholics. ${ }^{22}$ In 1926, a journalist wrote:

Vatican authorities are following with great interest the work of Consolata missionaries in Somalia, as their work is the first complete experiment the Pope has potentially created for the conversion of the Muslims... [The plan] could be explained as such: [missionaries should] first of all study Islamism deeply, the language, habits, the mentality of Muslim people, and then, through charity, address them directly, trying to earn their respect, then their love, eventually their soul. ${ }^{23}$

La Consolata depicted the apostolate as explicitly "experimental." 24 While the 1926 encyclical focused on evangelization in terms of preaching to the natives and building up native clergy and congregations, Consolata missionaries developed their own strategy as to fit best the reality of Italian

plan, in 1926 Pius XI also founded the Institute for Islamic Studies in Rome. La Consolata published several articles on Rerum Ecclesiae: "L'enciclica del Papa sulle Missioni," May, July, August, September, and October 1926, LC.

${ }^{21}$ See, for example, "Il solenne 'Te Deum' per il Governatore della Somalia,” June 1927; "Luci di redenzione nella Somalia Italiana. I grandiosi avvenimenti religiosi e civili con l'avvento del Figlio del Re," May, June, July, August, November, and December 1928, LC.

${ }^{22}$ On Church-State relations in Italy in the 1920s, see Lucia Ceci, The Vatican and Mussolini's Italy (Leiden: Brill, 2016).

${ }^{23}$ Published in "Il nostro esperimento tra i musulmani," October 1926, LC.

24 "Il nostro esperimento in Somalia," July 1926, and "Il nostro esperimento tra i musulmani," October 1926, LC. 
Somalia, where there were no Christian natives. In 1925, Gabriele Perlo, new Apostolic Administrator of the Benadir Vicariate, ${ }^{25}$ wrote:

We are in a wholly Muslim fieldwork and can pursue our direct apostolate only among the Italians ... and a few Catholic Eritreans who have moved here as workers, as well as among mixed-race children [meticci] and orphans of whom we take care. ${ }^{26}$

"With Muslims," another missionary wrote in 1926, "it is necessary to pursue other strategies [than direct apostolate]: education, labor, and Christian charity." 27 Consolata missionaries thus distinguished between "direct" and "indirect" apostolate. Direct apostolate addressed the already Christian segment of the population as well as its socially least integrated segment (foundlings) and consisted of catechism. Indirect apostolate involved the Muslim population and consisted in showing how magnanimous missionaries were by providing Muslims with various charity activities, including education and job opportunities.

To sum up, both the fascist colonial state and the Catholic Church espoused the cruce et aratro project, though from different perspectives and with different aims. On the one hand, De Vecchi was interested in training programs for the native youth (aratro) and Catholic services (cruce) to meet the labor and religious needs respectively of the emergent settler community. On the other hand, with the Pope's support Consolata missionaries aimed at providing direct Christian teaching among Italian and Eritrean Christians (cruce) while surreptitiously (indirectly) showing that missionaries were benefactors to the native Muslims.

${ }^{25}$ Cesare Pecorari to Filippo Perlo, 20 August 1924; Nomina ad Amministratore Apostolico della Prefettura del Benadir. Both in AIMC VII 13.

${ }^{26}$ Relazione 1925, AIMC VIII 6,1. See also: Giovanni Ciravegna, "Dalla Somalia Italiana. Il Primo nostro lavoro: le scuole," July 1925, LC.

${ }^{27}$ Giovanni Ciravegna, "Dalla Somalia Italiana. La via da seguire," March 1926, LC. Scholars have explored how notions of agricultural labor and salvation were mutually connected within missionary evangelism, which in given cases contributed to the emergence of intensive cultivation prior to the formal establishment of colonial rule. See, for example, John L. and Jean Comaroff, "Cultivation, Colonialism, and Christianity," Chapter 3 of Of Revelation and Revolution: Volume Two (Chicago: University of Chicago Press, 1997), 119-165. 
Charity and vocational education would give Muslims better opportunities in the job market (aratro). As a consequence of this close churchstate collaboration, the Apostolic Vicariate of Benadir increased its religious and missionary power in accordance with the colony's territorial expansion. ${ }^{28}$ Cross and plow, Italian and Vatican interests, colonial policy and missionary work went hand in hand for the first time in the history of Somalia.

In the years 1924 to 1930 , missionaries considerably expanded the Catholic network from Mogadishu, Gelib, and Brava to Villabruzzi, Merca, Afgoi, Gelib, Genale, Baidoa, Vittorio d'Africa, and Hafun. With De Vecchi's support, they founded missionary residences, hospitals, shelters for the poor and the elderly, leproseries, orphanages, agricultural settlements, and churches, including a monumental cathedral in Mogadishu. ${ }^{29}$ As La Consolata reported in July 1925, however, education was the very arena where missionaries could enact their "civilizing" plan with the same gradualism they had experimented in Kenya. ${ }^{30}$

${ }^{28}$ In 1927, the Vicariate was renamed Episcopal Prefecture of Somalia and Gabriele Perlo became the first bishop of Mogadishu. Both Somali Abyssinia and Jubaland, acquired by Italian Somalia in the 1920s but under the Vicariates of Djibouti and Zanzibar respectively, were annexed to the Prefecture so that the territories under Italian rule and those under the Prefecture would coincide. At first, only the governor was in favor of the expansion of the Vicariate to the rest of the colony, as he wanted the missionaries to found schools in the newly acquired territories. The CMI headquarters were contrary to the annexation of Jubaland to the Vicariate due to the lack of personnel and resources. See Francesco Gamberutti to Willem Marinus van Rossum, l January 1926, ASPF, Rubrica 39/10 N. S., Vol. 922, 4; Elevazione alla dignità episcopale e nomina a Vicario di Mogadiscio, AIMC VII 13. The Congregation for the Propagation of the Faith selected Gabriele Perlo as he had a very good relationship with the Italian authorities and by 1927 had already practiced a few years of apostolate in Somalia. See ASPF, Rubrica 39/10 N. S., Vol. 922, 56-73.

${ }^{29}$ Twenty-five male missionaries, including a few non-ordained, moved to Somalia, followed by more than thirty nuns of the female branch of CMI. See the list of missionaries in Padri della Prefettura Somalia, AIMC VIII 6,2, and Francesco Gamberutti, "L'operato dei missionari della Consolata nella Somalia Italiana," Atti del IV Congresso Nazionale della Società Antischiavista d'Italia, 1926.

${ }^{30}$ Ciravegna, "Dalla Somalia Italiana. Il Primo nostro lavoro: le scuole." 


\section{The Shaping of Colonial Education Under De VeCCHI (1923-28)}

In the 1920s, missionary work was officially regulated through a series of agreements signed by missionaries and governors. These negotiations fostered the creation, shaping, and progressive consolidation of Italian language schools in Somalia. Was there continuity between liberal and fascist approaches to colonial education? What were the prevailing pedagogies of the colonial state in Somalia? Can we trace trends and change over time during the first decade of fascist rule?

Italian Somalia's colonial school system-entirely controlled by missionaries-was born fifteen years after its official foundation as a colony in 1908. In July 1923, liberal authorities signed a two-year agreement on education with Trinitarian missionaries. The government would officially appoint missionaries to teach only the indigenous youth. ${ }^{31}$ The goal was to put an "experiment" in place, through which colonial authorities could "gradually find the final shape colonial schools will have to assume." Missionaries had to have earned a teaching license in the metropole but could be assisted by a non-licensed father with some missionary experience in Somalia. The government would provide for all the school materials and general expenses, as well as pay 3000 rupees per year to the mission. Classes had to be divided according to the "traditional division of the population" and "pedagogical exigencies as established by the government." As mentioned, any religious propaganda was strictly prohibited. School subjects included morals and civics, reading, writing, math, calligraphy, geography, and history of Italy and its colonies, drawing and practical arts. The detailed description of morals and civics teaching content is revealing in that it put great emphasis on the convenience of colonial rule and settled life (as opposed to vagrancy) as well as the division between Italian citizens and colonial subjects:

Morals and civics: respect of the elderly, women, disadvantaged, etc. Every man needs the other men - Advantages of civil life - Concept of residence Respect of public goods (property of all, result of common labor) - Goodness towards animals - Economy - Italian citizens and colonial subjects.

${ }^{31}$ I employ the terms Italo-Somali, meticci, indigenous, assimilated and Somali not as categories reflecting reality, but to refer to the racial categories used by Italian settlers in the 1920s. 
The state, the Residence is for everybody's convenience. Duties towards the Residence. Good use of time. Benevolence and solidarity. Not to do justice on your own. Concept of the state. ${ }^{32}$

Such an insistence on settled and civil life was not a mere matter of public order for De Vecchi. Lee Cassanelli's scholarship explains how vagrancy resulted from freed slaves' escape from colonial plantations and infrastructure building sites due to harsh working conditions. The colonial state considered it a prominent problem to contribute to the scarcity of available labor. ${ }^{33}$ By teaching the local youth not to leave the settler community, missionaries would encourage them to be reliable and loyal workers in the future.

In February 1924, after only six months, the agreement was changed and re-signed by both parties. With De Vecchi, fascism arrived in the colony and the anti-clerical liberal leadership left Somalia. First, the ban over evangelization was removed. Missionaries were appointed to open morning elementary schools for European children and evening (afterwork) elementary schools for indigenous adults, with preference for those working for the colonial government. The curriculum for indigenous students was the same as that attached to the previous agreement, with no mention of the subjects to be taught to Europeans. Also, while missionaries teaching the indigenous could be assisted by non-licensed evangelists, as established by the former contract, in the elementary schools for Europeans all instructors had to have earned a teaching license in the metropole. The funds provided by the government increased to 4500 rupees per year. ${ }^{34}$

After another ten months, in December 1924, the agreement was replaced with a new contract, this time between De Vecchi and Consolata missionaries. Elementary schools would provide day classes

${ }^{32}$ Carlo Riveri, "Convenzione con Trinitari sulle scuole," 9 July 1923, AIMC VIII 6,1. Italics added.

${ }^{33}$ On harsh working conditions and vagrancy, see Cassanelli, "The End of Slavery."

${ }^{34}$ Cesare Maria De Vecchi, "Decreto di approvazione convenzione con Trinitari sulle scuole," 22 February 1924, AIMC VIII 6,1. Consolata missionary activity was funded by the CMI, the Congregation for the Propagation of the Faith and other missionary or charity initiatives (including the Società antischiavista d'Italia), local alms, earnings from sales at the arts and crafts laboratories, and, above all, the Italian colonial government. See Informatio, 1927, ASPF, Rubrica 39/10 N. S., Vol. 922, 84-94. 
to, respectively, European and indigenous with assimilated children. ${ }^{35}$ The assimilated now appeared in the school hierarchy together with indigenous students. Regarding the teaching contents, classes would "follow the Italian national curriculum by and large with appropriate accommodations according to the students' age" and, as for evening classes, to the "practical aim" of those. Each father could be assisted by two nuns who were not required to have earned a diploma but only to be "expert at teaching." In addition to elementary schools, the mission would start vocational programs and a nursery school for both "mixed-race" foundlings (meticci) and Somali orphans, whose admission and religious education would be established by the government. The curriculum of vocational schools included woodwork, cabinet making, metalwork, and tinwork. Public funds remained at 4500 rupees per year, an amount that would increase over time had the governmental budget grown and "the school system been better organized [by missionaries]."36

In comparison with earlier prescriptions involving liberal authorities and Trinitarians, De Vecchi and Consolata missionaries negotiated several changes involving curriculum, funding, religious instruction, new categories of pupils (assimilated, meticci), qualification of instructors and the opening of vocational and nursery schools. Primary schooling was expanding (see Table 6.1) and provided assimilationist teaching (national curriculum, religious proselytism). Missionaries imported textbooks from Italy: teaching materials were national, not colonial. ${ }^{37}$ Yet, classes were increasingly segregated in accordance with racial categories. The appearance of vocational schooling and the "practical" character of native elementary education confirmed that, like for liberal authorities, the primary aim of missionary teaching among the native youth was to train skilled laborers and by doing so resolve the labor question in Italian Somalia.

\footnotetext{
35 "Assimilated" was the category the colonial authorities used for that segment of the population that was neither Italian nor African. "Assimilated" subjects did not have the Italian citizenship, but, in Italian colonies, were under the same legislation as the Italiansas opposed to colonial subjects, who were under "indigenous" law. See Bat-Zion Eraqi Klorman, "Yemen, Aden and Ethiopia: Jewish Emigration and Italian Colonialism," Journal of the Royal Asiatic Society 19, no. 4 (October 2009): 415-426.

${ }^{36}$ Agreement between Cesare Maria De Vecchi and Gabriele Perlo, 7 December 1924, AIMC VIII 6,1.

${ }^{37}$ Ciravegna, "Dalla Somalia Italiana. Il Primo nostro lavoro: le scuole."
} 
Table 6.1 School

Enrolment in Italian Somalia, 1924-1940 a

\begin{tabular}{lcc}
\hline School year & Native students & Italian students \\
\hline $1924-25$ & 326 & 0 \\
$1925-26$ & 667 & 6 \\
$1926-27$ & 995 & 15 \\
$1927-28$ & 1806 & 28 \\
$1928-29$ & 2456 & 37 \\
$1929-30$ & 1290 & 60 \\
$1930-31$ & 1683 & 65 \\
$1931-32$ & 1131 & 80 \\
$1932-33$ & 1793 & 91 \\
$1933-34$ & 1991 & 90 \\
$1934-35$ & 1115 & 92 \\
$1935-36$ & 1593 & 107 \\
$1936-37$ & 1714 & 100 \\
$1937-38$ & 2005 & 140 \\
$1938-39$ & No data & No data \\
$1939-40$ & 2010 & 249 \\
$1940-41$ & 1158 & 276 \\
\hline
\end{tabular}

aLe scuole della Somalia, ASDMAE-MAI III 36 3. I found the same statistics for the years 1922-1932 in Cesare Maria De Vecchi, Orizzonti d'Impero. Cinque anni in Somalia (Mondadori: Milan, 1935), 350 .

Expansion, centralization, and a combination of assimilation and segregation marked the emergence of the first school system in the colony.

Private letters and reports by Consolata missionaries illustrate how the cruce et aratro project and its legalization translated into everyday life. I focus on the years 1924-1928 (when the December 1924 agreement was in place) and proceed in accordance with school orders: nursery school, elementary, and post-elementary education.

In 1925, Consolata missionaries established an orphanage and nursery school for foundlings in Mogadishu. Their purpose was to provide charity to the socially marginal segment of the urban population and consequently "pacifically penetrate in" and "establish a direct contact with" local communities. ${ }^{38}$ Unable to propagandize their faith among Muslim families, missionaries turned to that segment of Somali society that occupied a liminal position: foundlings. The orphanage was thus a tool for

\footnotetext{
${ }^{38}$ Giovanni Ciravegna, "Dalla Somalia Italiana. L'asilo infantile di Mogadiscio," November 1926, LC.
} 
missionaries and De Vecchi to self-fashion themselves as benefactors and practice evangelization. On Christmas 1926, forty meticci were publicly baptized. Abandoned by their Italian fathers, they were raised by their Somali Muslim mothers. Missionaries intended to baptize twenty Somali orphans too but De Vecchi asked them to postpone their conversion. He believed that public baptisms of orphans from Muslim families could find the dissent of the Muslim community. It was a critical moment for the internal stability of the colony as the Italian Army was occupying its Northern borderland and tension was high. Eventually, missionaries baptized only the forty meticci. ${ }^{39}$ The twenty Somali orphans whose baptism had been denied by the governor were baptized two months later, in February 1927, after the Italian Army had completed the occupation of the Northern borderland. Another forty Somali orphans and five meticci were baptized in $1928 .{ }^{40}$ One of them was baptized in Italy, when missionaries organized a school trip to the metropole. ${ }^{41}$ However, in 1929 a nun recounted that she had secretly baptized a Somali child in periculo mortis: secret deathbed baptisms remained the norm throughout the 1920s (see Table 6.2). ${ }^{42}$

Sources do not provide enough information on the way children felt about conversion. Certainly, some form of coercion took place. In 1927, Gabriele Perlo wrote in a letter to a donor that Muslim mothers of met$i c c i$ were forced by the governor to enroll their children in the missionary nursery school, as they were "reluctant" and "diffident" and would never do it spontaneously. ${ }^{43}$ Another report says that in March 1928 thirty-four Somali orphans were baptized, which constituted a "success" given that prior to that event "many of them had repeatedly refused to be baptized." 44 Similarly, four documents from July to August 1928

\footnotetext{
${ }^{39}$ Cronistoria della Prefettura Apostolica della Somalia Italiana, 24 December 1926, AIMC VIII 6,2.

${ }^{40}$ Ibid., 11 March 1928.

41 "Festa di fede a Revigliasco per il battesimo d'un moretto somalo," November 1928, $L C$.

42 "Dal Vicariato di Mogadiscio," April 1929, LC. Another nun wrote about practicing secret baptisms in Suor Adele, "Il primo fiore sulla brulla duna," August 1927, LC. See also Relazione ordinaria dell'anno 1929, AIMC VIII 6,1: "We baptize dying babies while pretending we are curing them."

${ }^{43}$ Gabriele Perlo to Contessa, 5 February 1927, AIMC VII 13.

${ }^{44}$ Cronistoria della Prefettura Apostolica della Somalia Italiana, AIMC VIII 6,2.
} 
Table 6.2 Baptisms in Italian Somalia, 1925-1929a

\begin{tabular}{lclr}
\hline Year & $\begin{array}{l}\text { Secret deathbed baptisms of Somali } \\
\text { children in periculo mortis }\end{array}$ & Somali orphans & Meticci \\
\hline 1925 & 12 & 0 & \\
1926 & 23 & 40 & \\
1927 & 32 & 21 & 5 \\
1928 & 25 & 43 or 44 & 12 \\
1929 & 84 & 0 & \\
\hline
\end{tabular}

a compiled this chronological list of baptisms administrated in Italian Somalia (excluding baptisms of children from Christian families) by looking at Prospectus Missionis (an annual report sent by missionaries to the Congregation for the Propagation of Faith) and private missionary correspondence.

reported that two Muslim mothers implored the governor to have their respective children back from the missionary schools. ${ }^{45}$ These passages suggest that foundlings went to schools as a result of a coercive assimilation and evangelization policy.

The number of baptisms remained small. By 1929, five years after their arrival in the colony, missionaries had publicly baptized less than 150 people. The impact of missionary activity on Muslim communities was overall negligible, as the few baptisms involved a small, marginalized segment of the population. Yet, while Trinitarians struggled with the official ban over evangelization, Consolata missionaries, supported by the governor and the Holy See, tested a new strategy that allowed for the first appearance of Christianity in the colonial society. Overall, thus, the "civilization through the cross" undertaken by missionaries proved to be successful if compared to the liberal period. ${ }^{46}$

While legislation on proselytism corresponded to practice, this was not the case of racial segregation in elementary education. According

\footnotetext{
${ }^{45}$ Nicola Crocesi to Guido Corni, 3 September 1928, ASDMAE-Corni 1.

${ }^{46}$ Recent scholarship suggests that in the mid-1920s fascist authorities similarly collaborated with the Catholic Church in colonial expansion in Libya. See Eileen Ryan, Religion as Resistance: Negotiating Authority in Italian Libya (New York: Oxford University Press, 2018). In Eritrea, Catholic missionaries constituted only a portion of missionaries (the Protestant network was even more extended than the Catholic), and the local Orthodox Church was majoritarian: there was no colonial state church as it was the case in Somalia. See Cesare Marongiu Bonaiuti, Politica e religioni nel colonialismo italiano (1882-1941) (Milan: Giuffrè Editore, 1982), 426; Uoldelul Chelati Dirar, "Le religioni nella politica coloniale italiana," Africa e Mediterraneo 1 (1996): 9-14.
} 
to the 1924 Agreement, missionaries had to divide Italian from meticci and indigenous children. Yet, archival documents reveal that in Afgoi in 1925 Italian and indigenous students attended the same class, ${ }^{47}$ and in Brava, there was a school for white and meticci separated from a school for Muslims. ${ }^{48}$ In Mogadishu, in 1928 European and Italo-Somali students were in the same class. ${ }^{49}$ Also, in 1928 in Merca there was a school for Indians and in Baidoa one for both Eritrean and Somali members of the African section of the Italian colonial army. ${ }^{50}$ Classes for Indians and African soldiers, as well as the "mixing" of meticci, Italian and indigenous children did not reflect what the 1924 Agreement established. Reality reflected the overall process of slow adaptation and improvisation of missionaries to the life of the colony.

After elementary education, settlers' children went to middle school in Eritrea or Italy or were tutored privately by missionaries (the first middle school in Mogadishu was founded in 1932). Missionaries also opened a Latin class in Mogadishu in 1925 to allow Italian pupils to pursue their studies after elementary school, though no agreement formally mentioned Latin or in general education for Europeans after elementary schools. ${ }^{51}$ Improvisation, accommodation, and fortuity once again prevailed over prescription.

Missionaries often complained that available workers in Somalia were very hard to find. In the building of the cathedral in Mogadishu, they employed skilled free workers from Italy or local conscript laborers. They often lamented high life expenses, the absence of a printing house as well as affordable clothes and bread. ${ }^{52}$ The "indigenous" youth educated by missionaries would have provided for cheap skilled workforce.

\footnotetext{
${ }^{47}$ Gabriele Perlo to Filippo Perlo, 25 December 1925, AIMC VIII 6,1.

${ }^{48}$ Prima relazione integrale inviata alla S.C. di PF sullo stato della Prefettura Apostolica della Somalia Italiana, 1925, AIMC VIII 6,1.

${ }^{49}$ Giovanni Gaudissard, "Situazione scolastica nella Somalia italiana sotto i missionari della Consolata (1924-1930)," 3 August 1938, AIMC VIII 6,2.

${ }^{50} \mathrm{Ibid}$. The mention of "Indians" is not surprising as, since the Middle Ages, the Indian Ocean had been a much interconnected place, with many Indian merchants living along the East African coastline. See Trade, Circulation and Flow in the Indian Ocean World, ed. by Michael N. Pearson (Houndmills: Palgrave Macmillan, 2015).

${ }^{51}$ Gabriele Perlo to Filippo Perlo, 25 December 1925, AIMC VIII 6,1.

${ }^{52}$ For example: Gabriele Perlo to Filippo Perlo, 13 November 1924, AIMC VIII 6,1.
} 


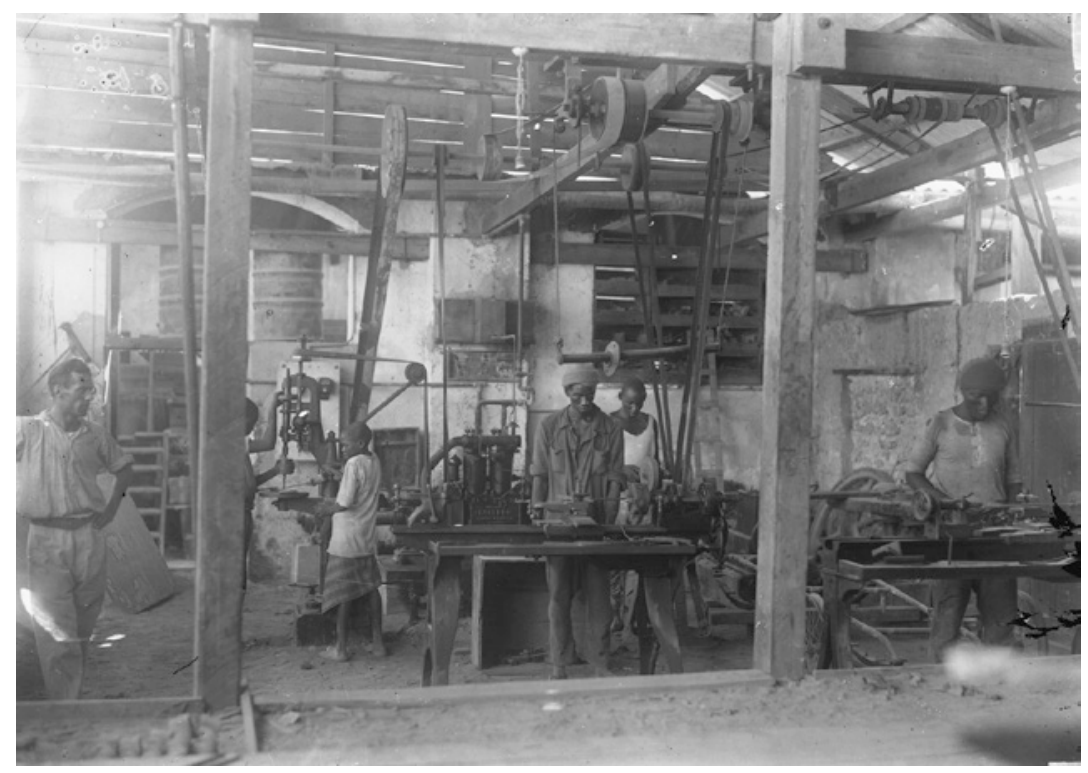

Fig. 6.1 A class for metalworkers (Mogadishu, 1928?) (Courtesy of AFIMC)

Thus, while elementary education was the same for all students, secondary education was divided into two different paths for Italians and Africans.

In 1925, La Consolata reported that native education aimed to "prepare the Somali to replace the Eritreans in the colonial office." ${ }^{53}$ As the Italian language school system had just been established in Somalia, there were not many locals speaking Italian or trained to work for colonial offices. As a result, colonial offices hired Eritreans, who spoke Italian because they had attended Italian schools in Eritrea. ${ }^{54}$ For settlers, it was more convenient to employ local workers as clerks, interpreters, and skilled labor in the colonies than importing Italian labor from the metropole. It would have been even more convenient to hire Somali people, as they knew the local language,

${ }^{53}$ Ciravegna, "Dalla Somalia Italiana. Il Primo nostro lavoro: le scuole."

${ }^{54}$ An Italian school system had been institutionalized in Eritrea in the previous decades. Christine Smith-Simonsen, "The Beginnings of Western Education in Eritrea," Eritrean Studies Review 5, no. 1 (2007): 259-309. 


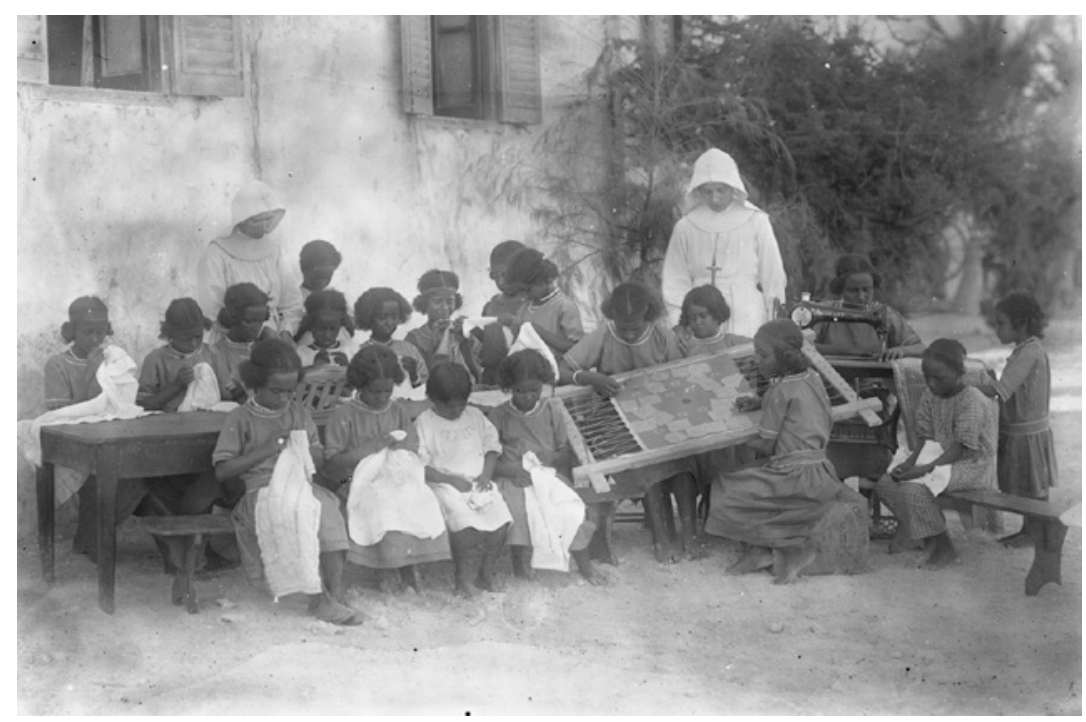

Fig. 6.2 A sewing class (Mogadishu, 1928?) (Courtesy of AFIMC)

and Eritrea could not provide for further workers as it was itself experiencing a high demand for labor. ${ }^{55}$ In Mogadishu, missionaries opened a male school of arts and crafts for woodworkers, smiths, printers, mechanics, and shoemakers, as well as a female school for sewing and domestic work (Figs. $6.1,6.2,6.3$, and 6.4). ${ }^{56}$ In 1927 , the two schools had started, respectively, a printing house, a bookbinder, a bakery, and a textile factory. ${ }^{57}$ Educational opportunities mirrored the labor needs of missionaries and the

${ }^{55}$ Stefano Bellucci and Massimo Zaccaria, "Wage Labor and Mobility in Colonial Eritrea, 1880s to 1920s," International Labor and Working-Class History 86 (2014): 89-106. On the labor question and employment of local workers in colonial settings, see Intermediaries, Interpreters, and Clerks: African Employees in the Making of Colonial Africa, ed. by Benjamin N. Lawrance et al. (Madison: The University of Wisconsin Press, 2006).

${ }^{56}$ Relazione 1925, AIMC VIII 6,1. On arts and crafts teaching, see also Giovanni Ciravegna, "Dalla Somalia Italiana: La Scuola di Arti e Mestieri a Mogadiscio," June 1927, and Alberto Gandino, "Dal vicariato di Mogadiscio il lebbrosario di Gelib sul Giuba," May 1929 , both in $L C$.

${ }^{57}$ Gabriele Perlo to Filippo Perlo, 3 October 1927, AIMC VIII 6,1. 


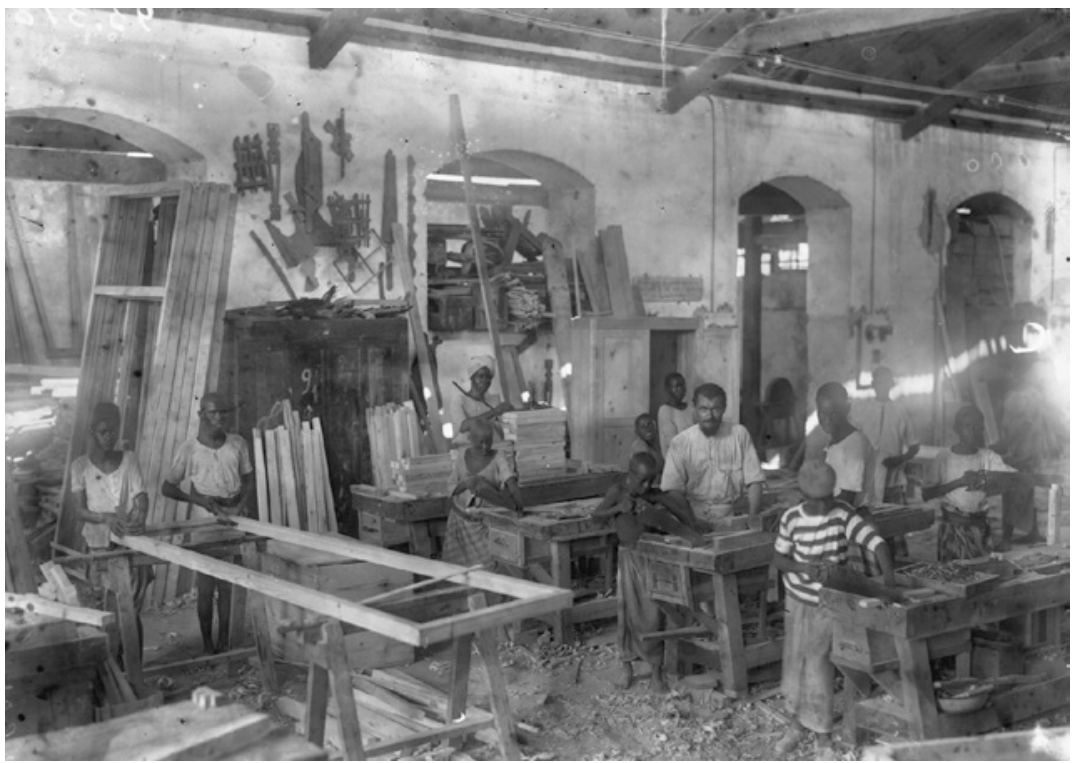

Fig. 6.3 A class for woodworkers (Mogadishu, 1928?) (Courtesy of AFIMC)

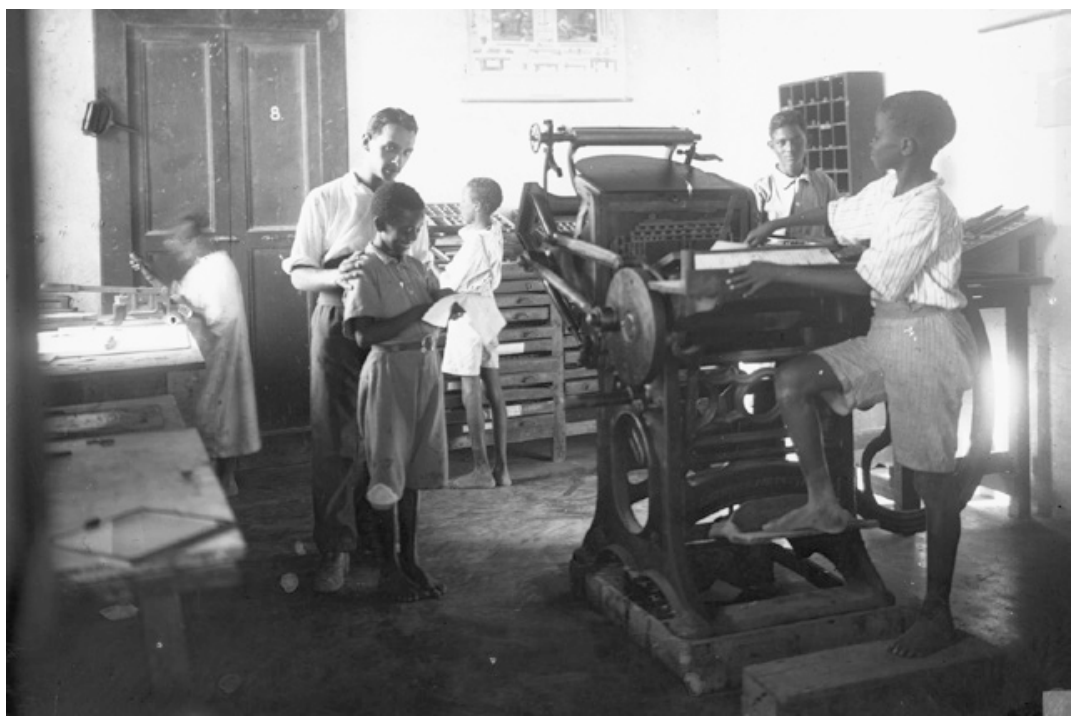

Fig. 6.4 A class for printers (Mogadishu, 1928?) (Courtesy of AFIMC) 
settler community as a whole. In this regard, in 1935 a Consolata missionary wrote about orphans that had attended missionary schools in the 1920s:

Nowadays, they work at the building site and the printing house, they are metal workers, drivers, civil clerks, and start founding Christian families. ${ }^{58}$

Private letters reveal that De Vecchi always agreed on missionary teaching strategies except once. In 1925 and 1926, Gabriele Perlo was rebuked by the mission's headquarters because he did not prohibit his fellow missionaries to smoke in public. The governor believed that such behavior undermined the image of religious men in front of both the Italian community living in the colony and the students attending missionary schools. ${ }^{59}$ Smoking was a bad habit that compromised the "holy" posture of missionaries. The reproach was probably ignored. In January 1927, a missionary published an article in La Consolata in which he described his work in the colony. "I will gladly tell you about my savages," he addressed the readers "[they are like] raw materials that missionaries aim to shape ... to Europeanize, to make them put a cigarette in their mouth," and "to Christianize." 60 According to the missionary, the aim of missionary education was to "Europeanize" their pupils by making them smokers and Christians. While the governor agreed on the latter, he was certainly skeptical toward the former.

Missionaries significantly contributed to non-educational activities as well. In 1924, De Vecchi assigned them a 99-year agricultural concession of four-hundred hectares in the fertile Southern region of the colony for an annual rent in rupees. ${ }^{61} \mathrm{CMI}$ could increase funds for education and other missionary activities through agricultural work. ${ }^{62}$ In this respect, I found five depositions from July 1929 that document missionaries' abusive practices toward agricultural workers. Interviewees were all local workers that had escaped from plantations and, with the help of police-appointed translators, had officially accused missionaries of providing very little money and food, as well as beating and threatening them with

\footnotetext{
58 "Storia della Missione," December 1935, Somalia Cristiana.

${ }^{59}$ Filippo Perlo to Gabriele Perlo, 3 August 1925 and 6 January 1926, AIMC VIII 6,3.

60 “Colloqui missionari," January 1927, LC.

${ }^{61}$ Cesare Maria De Vecchi, Decreto 4181, 17 January 1925, AIMC VIII 6,1.

${ }^{62}$ Gabriele Perlo to Filippo Perlo, 13 December 1924, AIMC VIII 6,1.
} 
death if they had stopped working. ${ }^{63}$ The fathers' abuses most probably reflected the overall behavior of the Italian settler community toward local workers $^{64}$; they did not actively oppose but rather took advantage of the well-spread coercive practices of labor recruitment and exploitation.

Missionaries also had a role in the policy of morals in Mogadishu. According to an official report on "indigenous prostitution" documented sometime between 1928 and 1931, Gabriele Perlo joined De Vecchi's wife in the active opposition to the institution of regulated brothels (case di tolleranza). ${ }^{65}$ Through both educational and non-educational activities the fathers occupied a leading role within the settler community. While liberals considered the Catholic Church as an old, superstitious body, in the 1920s De Vecchi appointed missionaries as agents of modernization in the development of Somalia.

\section{Towards Adapted Education, 1930s}

The December 1924 contract was revised in June 1928.66 The new governor Guido Corni (1928-1931), De Vecchi's successor, requested Consolata missionaries to provide for at least twenty-five instructors and follow the teaching plan indicated by the colonial government (but not attached to the agreement). The governmental check was increased from 10,400 to 22,600 lire per month ${ }^{67}$ and missionary elementary schools were proclaimed "state governmental schools." 68 In continuity with De Vecchi's policy, Corni encouraged the progressive expansion and centralization of colonial education by increasing funds and making missionary

${ }^{63}$ See correspondence and interviews from 1929 in the file "Missioni Consolata. Lettere Vescovo Perlo," ASDMAE-Corni 1.

${ }^{64}$ Cassanelli, "The End of Slavery."

${ }^{65}$ Prostituzione Indigena, ASDMAE-Corni $12 / 3$.

${ }^{66}$ Agreement between Giovanni Pellettieri and Gabriele Perlo, 1 June 1928, ACS-MAI 160.

${ }^{67}$ In 1925 , the Italian lira had replaced the local rupee with a ratio $1: 8$. On this topic, see Tuccimei, La Banca d'Italia in Africa, 149-151.

${ }^{68}$ Guido Corni to Benito Mussolini, 1 July 1929, ACS-MAI 160; for the increase of the funds, see Pietro Gaveglio to Guido Corni, Promemoria sull'istruzione, 30 September 1928, ASDMAE-Corni $12 / 8$. 
schools officially public. In opposition to De Vecchi, though, Corni proposed a shift from assimilationist to adapted teaching. He wrote that he was contrary to the Christian evangelization of native students, ${ }^{69}$ and that his government would have paid greater attention to native schooling and particularly to both vocational and Arabic language teaching. ${ }^{70}$ After 1928, missionaries had to follow not the national, but the colonial curriculum. Further, the lack of any curriculum attached to the agreement allowed the government to change it at any given time. In 1930, both Italian and Vatican authorities commanded Consolata Fathers to leave the colony due to some unspecified scandal within the mission. The Congregation for the Propagation of the Faith replaced them with Capuchin missionaries, while Consolata nuns continued working as nurses and teachers in Somalia. ${ }^{71}$

Such a new policy of curriculum adaptation did indeed proceed in the early 1930s, as shown, for example, by the publication in 1933 of the "First Italian Language Book for the Somali" (Primo libro di italiano per somali). The author, a Capuchin missionary, included language exercises on the greatness of Italy, but also on "Allah," as well as images of mosques and local flora and fauna. The mention of Allah would have been unthinkable in the 1920s, when Consolata missionaries and De Vecchi pushed for Christian teaching in the curriculum. One of the textbook readings, titled "Story of a gazelle" (Storia di una gazzella), told how a female gazelle, after losing her husband to hunters, wandered around in search for her friends. When she came across a village, she decided not to stop and went on wandering until a lion killed her. The story ended with a short explanation:

\footnotetext{
${ }^{69}$ Correspondence between Guido Corni and Nicola Crocesi, 25, 27, and 28 August 1928, 3 September 1928, ASDMAE-Corni 1 10/3.

${ }^{70}$ Guido Corni, Rapporto sull'opera di governo svolta dal 23 luglio al 30 settembre 1928, ASDMAE-Corni 1.

${ }^{71}$ Neither Italian nor Vatican sources mention the actual scandal and the reasons why the Congregation sent Capuchins to Italian Somalia. A few letters refer to the promiscuous relations between Consolata nuns and fathers, while others to fathers' venal attitude and conflict of interest with respect to the mission-assigned agricultural concession. A 1930dated entry of De Vecchi's posthumously published diary confirms the latter hypothesis. See AIMC VIII 6,1 and 6,3; ASPF, Rubrica 39/10 N. S., Vol. 1034; Cesare Maria De Vecchi, Tra papa, duce e re: il conflitto tra Chiesa cattolica e Stato fascista nel diario 1930-1931 del primo ambasciatore del Regno d'Italia presso la Santa Sede, ed. by Sandro Setta (Rome: Jouvence, 1998), April 14, 1930, 138.
} 
Teaching: we must stay united and loyal to our family, people, laws; because those who want to go vagabond in the world always ... suffer starvation, meet serious risks and, like the gazelle, end up being eaten by lions, meaning by the arrogant. ${ }^{72}$

The main purpose of the gazelle's story was to alert children against vagrancy and prevent them from escaping their fate as loyal subjects and productive workers under the Italians. As under liberal rule, Corni discouraged (but never prohibited) the cross and highlighted the plow. Differentiation also reflected the up-bringing of meticci. While Consolata missionaries and De Vecchi pursued assimilationist teaching among them in the 1920s, Capuchin missionaries wrote in 1930:

For the spiritual formation of meticci, so far educated according to a teaching strategy that is not conform with their origin and future, I have disposed that the director of studies provides life regulations better fitting their social position, so that later in life they will be able to earn honestly while preserving their Catholic faith. ${ }^{73}$

The colonial state opened a middle school and a high school for Italians in Mogadishu respectively in 1932 and 1937. The only educational option for non-Italians remained mission-run vocational education, lasting until the establishment of a middle school for Somalis in $1950 .{ }^{74}$ To retrace the social and economic repercussions of the 1928 Agreement and the overall policy of curriculum adaptation remains a research perspective worth exploring in the future. ${ }^{75}$

\footnotetext{
${ }^{72}$ Daniele Gorlani, Primo libro di italiano per somali (Mogadishu: Regia Stamperia della Colonia, 1933), 104.

${ }^{73}$ ASPF, Rubrica 39/10 N.S., Vol. 1034, 375-376.

${ }^{74}$ Le scuole della Somalia, ASDMAE-MAI III 36, 3.

${ }^{75}$ At this stage of the research, I have not been able to examine the local reception and impact of the 1928 Agreement and subsequent changes in missionary teaching due to the scarce and fragmentary nature of the 1930s' first-hand accounts by Capuchins. While I have not yet found the documentation produced by in-loco fathers, I could get access to the official correspondence of Capuchins' headquarters, which confirms the fathers' departure for Somalia. See AOFM SM/152-1 and SM/152-2.
} 


\section{CONCLUSION}

Corni's shift from assimilationist to adapted curriculum is not surprising if placed in the broader context of racial thinking and religious policy in 1930s Italian colonialism. By then, a more rigid and biologically based racial hierarchy emerged throughout the empire, which had an impact on colonial discourse, prescription, and practice. In this respect, the treatment of "mixed-race" children is exemplary. In 1933, a law established that meticci received full Italian citizenship when they were not officially recognized by their fathers, who were to blame for that; after 1935, the fascist regime established a rigid colonial hierarchy based on biological racism and the purity of race. According to a 1940 law, the meticci were colonial subjects and could not receive Italian citizenship given their African heritage. Historians have interpreted such shift as a product of the climate of suspicion and state surveillance brought about by the Second Italo-Ethiopian War, where fascist Italy was diplomatically isolated and employed racial differentiation as a tool of governance in the Horn of Africa. ${ }^{76}$ The matter goes beyond this essay's research goals, but it is still important to locate the transition from assimilationist to adapted curriculum in Italian Somalia within an imperial transition toward racial legislation and segregation. Further, in the 1930s Mussolini launched a pro-Muslim and pro-Arab policy in order to find military and economic partners in the Middle East and to pacify anti-colonial unrest in Muslim-majoritarian Libya. This policy culminated in the late 1930s, when, after the incorporation of Ethiopia, about nine million Muslims were under Italian rule. Not only did fascist propagandistic publications circulated in the Arab world as never before, but in 1937 Mussolini self-proclaimed himself "protector of Islam" in Tripoli. I suggest that apparently opposite trends in colonial and foreign politics converged in the integration of Islamic elements into missionary teaching. While the emergence of racial law resulted in the increase of curriculum differentiation, Mussolini's simultaneous

\footnotetext{
${ }^{76}$ Giulia Barrera, "Patrilinearity, Race, and Identity: The Upbringing of Italo-Eritreans During Italian Colonialism," in Italian Colonialism, ed. by Ruth Ben-Ghiat and Mia Fuller (New York: Palgrave Macmillan, 2005), 97-108. See also Gianluca Gabrielli, "Un aspetto della politica razzista nell'Impero: il «problema dei meticci»," Passato e presente XV, no. 41 (1997): 77-105; Barbara Sòrgoni, Parole e corpi. Antropologia, discorso giuridico e politiche sessuali interraziali nella colonia Eritrea (1890-1941) (Naples: Liguori, 1998).
} 
pro-Arab policy allowed for the teaching of Islam among Muslim students. ${ }^{77}$

The history of missionary education in Italian Somalia during the first decade of fascist rule is overall not surprising either when placed in the history of global education and European colonialism. As explained by the editors in the general introduction to this volume, historians have recently shown how the inter-war period constituted a transitional phase in the "civilizing mission" discourse and practice. As the League of Nations proclaimed the "well-being and development of peoples" a "sacred trust of civilization," both British and French officials increasingly justified their policies as aimed toward native development and consequent rise in native life standards. ${ }^{78}$ Published in 1922 and 1925, two inter-colonial reports on the state of native education in sub-Saharan Africa inaugurated a debate on colonial rule and mission. ${ }^{79}$ The emergent model of native education-adapted education-fused developmentalist theories with practices that had been experimented with the education of African Americans in the United States in the previous decades. ${ }^{80}$ Further, historians have highlighted how the 1919 peace treaty revising the General Acts of Berlin and Brussels established that, while native labor should be free and paid, compulsory labor could be imposed for public works that were in the general interest. Notions of "civilization through labor" and "redemptive labor" were internationally legitimized and increasingly pervaded British, French, and Portuguese

${ }^{77}$ On Islam in Italian colonial and foreign policy, see Nir Arielli, Fascist Italy and the Middle East, 1933-1940 (New York: Palgrave Macmillan, 2010); Federico Cresti, "Per uno studio delle 'Elites' politiche nella Libia indipendente: la formazione scolastica (1912-1942)," Studi Storici 41, no. 1 (2000): 121-158; Renzo De Felice, Il Fascismo e l'Oriente. Arabi, Ebrei e Indiani nella politica di Mussolini (Bologna: Il Mulino, 1988); Francesca Di Pasquale, "La scuola di arti e mestieri di Tripoli in epoca coloniale (19111938)," Africa LXII, no. 3 (2007): 299-428; John Wright, "Mussolini, Libya, and the Sword of Islam," in Italian Colonialism, ed. by Ruth Ben-Ghiat and Mia Fuller (New York: Palgrave Macmillan, 2005), 121-130.

${ }^{78}$ Hodge et al., Introduction of Developing Africa, 1-34.

${ }^{79}$ Neither reports covered Italian Somalia. Thomas Jesse Jones, Education in Africa: A Study of West, South and Equatorial Africa, by the African Education Commission (New York: Phelps-Stokes Fund, 1922); Id., Education in East Africa; a Study of East, Central and South Africa by the Second African Education Commission Under the Auspices of the Phelps-Stokes Fund, in Cooperation with the International Education Board (New York: Phelps-Stokes Fund, 1925).

${ }^{80}$ Kallaway and Swartz, Introduction of Empire and Education in Africa, 1-28. 
plans of "civilizing mission" or "development" for future political emancipation of African lands and peoples. ${ }^{81}$

The cruce et aratro project, I ultimately argue, belongs to this history. In the inter-war Italian Somalia context, the search for labor was the very motor of public-school building and reflected worldwide practices of native education. Moreover, fascist colonial authorities in the late 1920s and early 1930s placed a greater emphasis on education and promoted a shift toward adapted curriculum. In terms of structure, aims, teaching contents, and actors, the cruce et aratro project was not unique. This essay has illustrated how it came into being as a result of the convergence of church and state agendas in a peculiar colonial context, and to what extent prescription and practice corresponded and changed in the first years of fascist rule. Further scholarship awaits on how international debates and politics informed fascist educational policy and practice in Italian colonies.

Acknowledgements I am grateful to the Consolata Missions Institute archivists Carmen and Luigi, in Rome and Turin respectively, for their kind willingness to share materials with me in person or from afar. I would also like to thank the editors of the present volume, audiences in Chicago, Bologna, and Leuven, as well as Ismael Biyashev, Luigi Cajani, Kirk Hoppe, Lynn Hudson, and Filippo Petricca for their intellectual support and inspiring feedback on this and earlier versions of the chapter.

\section{BIBLIOGRAPHY}

Ahmed, Hassan O. "Sul primo decennio dell'era fascista in Somalia." In Proceedings of the Third International Congress of Somali Studies, edited by Annarita Puglielli and Francesco Antinucci, 291-297. Rome: Pensiero Scientifico, 1988.

Arielli, Nir. Fascist Italy and the Middle East, 1933-1940. New York: Palgrave Macmillan, 2010.

Bandeira Jéronimo, Miguel. The 'Civilising Mission' of Portuguese Colonialism, 1870-1930. Houndmills: Palgrave Macmillan, 2015.

Barrera, Giulia. "Patrilinearity, Race, and Identity: The Upbringing of ItaloEritreans During Italian Colonialism." In Italian colonialism, edited by Ruth Ben-Ghiat and Mia Fuller, 97-108. New York: Palgrave Macmillan, 2005.

${ }^{81}$ Miguel Bandeira Jéronimo, The 'Civilising Mission' of Portuguese Colonialism, 1870 1930 (Houndmills: Palgrave Macmillan, 2015). 
Bellucci, Stefano, and Massimo Zaccaria. "Wage Labor and Mobility in Colonial Eritrea, 1880s to 1920s." International Labor and Working-Class History 86 (2014): 89-106.

Benedict XV. Maximum Illud. Apostolic letter, November 30, 1919. Vatican website, accessed 28 February 2019. http://w2.vatican.va/content/benedict-xv/en/apost_letters/documents/hf_ben-xv_apl_19191130_maximum-illud.html.

Calchi Novati, Gian Paolo. L'Africa d'Italia. Una storia coloniale e postcoloniale. Rome: Carocci, 2011.

Carcangiu, Bianca Maria. "I Missionari della Consolata nella Somalia italiana (1925-1930)." In Studi mediterranei ed extraeuropei, edited by Vittorio Antonio Salvadorini, 147-174. Pisa: Edistudio, 2002.

Cassanelli, Lee V. "The End of Slavery and the «Problem» of Farm Labor in Colonial Somalia." In Proceedings of the Third International Congress of Somali Studies. History, Anthropology and Archaeology, edited by Annarita Puglielli and Francesco Antinucci, 269-282. Rome: Pensiero Scientifico, 1988.

Ceci, Lucia. Il vessillo e la croce. Colonialismo, missioni cattoliche e islam in Somalia (1903-1924). Bologna: Il Mulino, 2006.

- The Vatican and Mussolini's Italy. Leiden: Brill, 2016.

Chelati Dirar, Uoldelul. "Le religioni nella politica coloniale italiana." Africa $e$ Mediterraneo 1 (1996): 9-14.

Cresti, Federico. "Per uno studio delle 'Elites' politiche nella Libia indipendente; la formazione scolastica (1912-1942)." Studi Storici 41, no. 1 (2000): $121-158$.

Comaroff, John L., and Jean. Of Revelation and Revolution: Volume Two. Chicago: Chicago University Press, 1997.

De Felice, Renzo. Il Fascismo e l'Oriente. Arabi, Ebrei e Indiani nella politica di Mussolini. Bologna: Il Mulino, 1988.

De Vecchi, Cesare Maria. Orizzonti d'Impero. Cinque anni in Somalia. Milan: Mondadori, 1935.

- Tra papa, duce e re: il conflitto tra Chiesa cattolica e Stato fascista nel diario 1930-1931 del primo ambasciatore del Regno d'Italia presso la Santa Sede, edited by Sandro Setta. Rome: Jouvence, 1998.

Declich, Francesca. "Italian Weddings and Memory of Trauma: Colonial Domestic Policy in Southern Somalia, 1910-1941." In Marriage by Force? Contestation over Consent and Coercion in Africa, edited by Annie Bunting et al., 70-83. Athens: Ohio University Press, 2016.

Del Boca, Angelo. Italiani Brava Gente? Un mito duro a morire. Venice: Neri Pozza, 2005.

Di Pasquale, Francesca. "La scuola di arti e mestieri di Tripoli in epoca coloniale (1911-1938)." Africa LXII, no. 3 (2007): 299-428. 
Eraqi Klorman, Bat-Zion. "Yemen, Aden and Ethiopia: Jewish Emigration and Italian Colonialism." Journal of the Royal Asiatic Society 19, no. 4 (2009): 415-426.

Gabrielli, Gianluca. “Un aspetto della politica razzista nell’Impero: il «problema dei meticci»." Passato e presente XV, no. 41 (1997): 77-105.

Gorlani, Daniele. Primo libro di italiano per somali. Mogadishu: Regia Stamperia della Colonia, 1933.

Hess, Robert L. Italian Colonialism in Somalia. Chicago: The University of Chicago Press, 1966.

Hodge, Joseph M., et al., ed. Developing Africa: Concepts and Practices in Twentieth-Century Colonialism. Manchester: Manchester University Press, 2014.

Jones, Thomas Jesse. Education in Africa: A Study of West, South and Equatorial Africa, by the African Education Commission. New York: Phelps-Stokes Fund, 1922.

- Education in Africa; a study of East, Central and South Africa by the Second African Education Commission Under the Auspices of the Phelps-Stokes Fund, in Cooperation with the International Education Board. New York: Phelps-Stokes Fund, 1925.

Kallaway, Peter, and Rebecca Swartz, eds. Empire and Education in Africa: The Shaping of a Comparative Perspective. New York: Peter Lang, 2016.

Labanca, Nicola. "Italiani d'Africa." In Adua. Le ragioni di una sconfitta, edited by Angelo Del Boca, 193-230. Bari: Laterza, 1998.

Lawrance, Benjamin N., et al., eds. Intermediaries, Interpreters, and Clerks: African Employees in the Making of Colonial Africa. Madison: The University of Wisconsin Press, 2006.

Marongiu Bonaiuti, Cesare. Politica e religioni nel colonialismo italiano (1882-1941). Milan: Giuffrè Editore, 1982.

Morone, Antonio. "Politica e istruzione nella Somalia sotto tutela italiana." In Colonia e Postcolonia come spazi diasporici, edited by Uoldelul Chelati Dirar et al., 75-92. Rome: Carocci, 2011.

Naletto, Andrea. Italiani in Somalia. Storia di un colonialismo straccione. Padua: Cierre edizioni, 2001.

Natilli, Daniele. "Le missioni cattoliche italiane all'estero: il caso della Consolata nella Somalia di Cesare Maria De Vecchi (1924-1928)." A.S.E.I. (7 November 2011), accessed 28 February 2019, https://www.asei.eu/ it $/ 2011 / 11 /$ le-missioni-cattoliche-italiane-allestero-il-caso-della-consolata-nella-somalia-di-cesare-maria-de-vecchi-1924-1928/.

Pandolfo, Michele. "La Somalia coloniale: una storia ai margini della memoria italiana." Diacronie 14, no. 2 (2013): 1-18.

Pearson, Michael N., ed. Trade, Circulation and Flow in the Indian Ocean World. Houndmills: Palgrave Macmillan, 2015. 
Pius XI. Rerum Ecclesiae. Encyclical Letter, 28 February 1926. Vatican website, accessed 28 February 2019, http://w2.vatican.va/content/pius-xi/en/ encyclicals/documents/hf_p-xi_enc_28021926_rerum-ecclesiae.html.

Podestà, Gianluca. Il mito dell'impero. Economia, politica e lavoro nelle colonie italiane dell'Africa orientale 1898-1941. Turin: G. Giappicchelli Editore, 2004.

Ryan, Eileen. Religion as Resistance: Negotiating Authority in Italian Libya. New York: Oxford University Press, 2018.

Sbacchi, Alberto. "The Archives of the Consolata Mission and Italian Colonialism." In vol. I of Fonti e problemi della politica coloniale italiana: atti del convegno Taormina-Messina, 23-29 ottobre 1989, edited by Carla Ghezzi, 87-112. Rome: Ministero per i beni culturali e ambientali, Ufficio Centrale per i beni archivistici, 1997.

Smith-Simonsen, Christine. "The Beginnings of Western Education in Eritrea," Eritrean Studies Review 5, no. 1 (2007): 259-309.

Sòrgoni, Barbara. Parole e corpi. Antropologia, discorso giuridico e politiche sessuali interraziali nella colonia Eritrea (1890-1941). Naples: Liguori, 1998.

Tesolin, Riccardo. Investire in colonia. Somalia italiana e Côte Française des Somalis 1920-1960. M.A. thesis, University of Bologna, 2018.

Tuccimei, Ercole. La Banca d'Italia in Africa. Bari: Laterza, 1999.

Urbano, Annalisa. "A 'Grandiose Future for Italian Somalia': Colonial Developmentalist Discourse, Agricultural Planning, and Forced Labor (19001940)." International Labor and Working-Class History 92 (2017): 69-88.

Wright, John. "Mussolini, Libya, and the Sword of Islam." In Italian Colonialism, edited by Ruth Ben-Ghiat and Mia Fuller, 121-130. New York: Palgrave Macmillan, 2005.

Open Access This chapter is licensed under the terms of the Creative Commons Attribution 4.0 International License (http://creativecommons.org/licenses/ by $/ 4.0 /$ ), which permits use, sharing, adaptation, distribution and reproduction in any medium or format, as long as you give appropriate credit to the original author(s) and the source, provide a link to the Creative Commons license and indicate if changes were made.

The images or other third party material in this chapter are included in the chapter's Creative Commons license, unless indicated otherwise in a credit line to the material. If material is not included in the chapter's Creative Commons license and your intended use is not permitted by statutory regulation or exceeds the permitted use, you will need to obtain permission directly from the copyright holder.

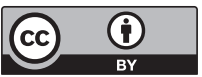

